\title{
Studies on the Pathogenesis of the Pseudohermaphroditism in the Mouse with Testicular Feminization
}

\author{
Joseph L. Goldstein and Jean D. Wilson \\ From the Department of Internal Medicine, The University of Texas Southwestern \\ Medical School, Dallas, Texas 75235, and the Division of Medical Genetics, \\ Department of Medicine, University of Washington, \\ Seattle, Washington 98105
}

A B S T R A T The pathogenesis of the male pseudohermaphroditism in the mouse with $\mathrm{X}$-linked testicular feminization ( $T f m$ ) has been investigated by comparing testosterone formation, the effects of androgen administration, and the metabolism of testosterone- $1,2-{ }^{3} \mathrm{H}$ in normal mice and $T f m$ mice of varying ages. First, it was established that the adult $T \mathrm{fm}$ animal, in contrast to the human with testicular feminization, has both a low serum testosterone and a low rate of testosterone formation as assessed in slices of testes utilizing a variety of precursors. However, the formation of testosterone from pregnenolone- $7 \alpha-{ }_{-}^{3} \mathrm{H}$ was shown to be normal in newborn $T f m$ testes, suggesting that a defect in testosterone synthesis may not be primary to this mutation. Second, to establish that the pseudohermaphroditic state is due to androgen resistance rather than to diminished androgen biosynthesis during fetal life, the effect of the administration of dihydrotestosterone to pregnant animals was studied in male, female, and Tfm offspring. Whereas normal and carrier female littermates demonstrated striking virilization of the internal genital tract after such treatment, there was no sign of virilization in the Tfm animals. This finding provides direct experimental evidence in support of the view that male pseudohermaphroditism in testicular feminization is the result of resistance to androgen action during androgen-mediated sexual differentiation in embryos. Third, the metabolism of testosterone-1,2- ${ }^{3} \mathrm{H}$ was investigated both in tissue slices and in functionally hepatectomized animals. Dihydrotestosterone formation in tissue slices of the fetal anlage of the male organs of accessory reproduction is normal in the $T f m$ animal, suggesting that the primary defect in this disorder involves an intracellular event subsequent

Dr. Goldstein is the recipient of a Special National Institutes of Health Fellowship GM 47841-01.

Received for publication 1 November 1971 and in revised form 14 February 1972. to this step and that the deficient dihydrotestosterone formation observed in the adult genital tract of the $T \mathrm{fm}$ mouse is secondary to the failure of differentiation in these tissues. Finally, deficient binding of testosterone in the nuclei of the submandibular gland of adult $\mathrm{Tfm}$ animals, a known testosterone target tissue, was demonstrated in functionally hepatectomized mice. This finding could either be a manifestation of the primary genetic defect in this disorder or might reflect another acquired abnormality due to incomplete differentiation of adrogensensitive cell lines.

\section{INTRODUCTION}

An inherited syndrome of testicular feminization has now been described in several species in addition to man (1), including the cow (2), the $\operatorname{dog}(3)$, the rat $(4,5)$, and the mouse $(6,7)$. In those species in which the disorder has been characterized in detail, the affected male pseudohermaphrodites manifest several features in common, namely external genitalia and breasts characteristic of phenotypic females, an absence of internal genitalia other than the testes, and striking resistance to endogenous and exogenous androgens (5, 7-9). Indeed, in accordance with the theories formulated by Wolff (10), by Jost $(11)$, and by others $(12,13)$ that the differentiation of the male internal and external genitalia is mediated by androgen secreted by the fetal testes, it has been assumed that resistance to the action of testosterone $^{1}$ is the primary defect in this condition and that

\footnotetext{
${ }^{1}$ Abbreviations and trivial names used in this paper: androstenedione, androst-4-ene-3,17-dione; androsterone, $3 \alpha$ hydroxy-5 $\alpha$-androstan-17-one; dihydrotestosterone, $17 \beta$-hydroxy-5 $\alpha$-androstan-3-one; 17 -hydroxy-pregnenolone $3 \beta, 17 \alpha$ dihydroxy-preg-5-en-20-one; 17-hydroxy-progesterone, $17 \alpha$ hydroxy-preg-4-ene-3,20-dione; pregnenolone, $3 \beta$-hydroxypreg-5-en-20-one; progesterone, preg-4-en-3,20-dione; Ta, Tabby gene; testosterone, $17 \beta$-hydroxyandrost-4-en-3-one; $T f m$, testicular feminization.
} 
the failure of male differentiation of the internal and external genitalia during embryogenesis is secondary to this abnormality in testosterone action (5-9). In keeping with this hypothesis, a number of recent studies have appeared attempting to explain the biochemical basis of the androgen resistance in testicular feminization. For example, in testicular feminization in man the conversion of testosterone to its active derivative dihydrotestosterone is deficient in perineal skin (14-16). In affected rats (17) and in affected mice $(18,19)$ it has been reported that the intracellular binding of androgen in target tissues, such as the preputial gland and the kidney, is diminished despite normal rates of dihydrotestosterone formation.

These conflicting results can be explained in one of several possible ways. First, genetic heterogeneity of the testicular feminization phenotype might exist among the different species or even within the same species, and this would be expected to result in different biochemical abnormalities in the various affected animal or human subjects despite similarities in the resulting phenotypes. Second, all studies to date both in man and in affected animals have been performed on tissues taken either from sexually mature subjects or from humans several years after the completion of sexual differentiation, and although these accessory sex tissues are normally dependent on androgen for growth and function, they may have differentiated in these mutants without androgen dependent elements. Consequently, it is not known whether any of the various defects reported in this syndrome in man and in animals are primary manifestations of the mutant gene(s) or whether they represent secondary effects of some earlier failure of androgen action which occurred during embryonic sexual differentiation. In fact, at the present time it is unclear whether the cellular mechanisms that mediate androgen action physiologically in the differentiating embryo are identical to those that are thought to mediate growth and function of mature tissues. It is also not known which of the features of testosterone metabolism presumed to be essential to the action of the hormone in the adult might be the consequence of some earlier androgen action in the embryo.

A series of studies was designed, therefore, to investigate the pathogenesis of the male pseudohermaphroditism in the mouse with testicular feminization $(T f m)$ by examining systematically the effect of the $T f m$ mutation on the synthesis of androgen, on the action of androgen during differentiation, and on the metabolism of radioactive testosterone. These processes were studied in the anlage of the internal and external genitalia of affected newborn mice before complete tissue atrophy and compared with those of the analogous differentiated tissues of normal newborn and adult mice in order to distin- guish between primary and secondary manifestations of the genetic defect in the testicular feminization syndrome. The results outlined below indicate that in this mutant the failure of male sexual differentiation is indeed the result of a primary resistance to the action of androgen during embryogenesis; that several of the features of the syndrome observed in the adult mouse, including diminished dihydrotestosterone formation and decreased testosterone biosynthesis, are secondary to this fundamental defect; and that the basis of the androgen resistance appears to involve an intracellular event that occurs after the conversion of testosterone to dihydrotestosterone.

\section{METHODS}

Treatment of animals. The mice used in these experiments were from a colony developed from two carrier $T \mathrm{fm}$ females that were the gift of Dr. S. Ohno. One of these females carried the tabby mutation $(T a)$ on the other $\mathrm{X}$ chromosome $(T f m / T a)$. Since the tabby gene is closely linked to the $T f m$ mutation in these animals (6), matings between $T a / T f m$ females and $T a / Y$ males were used in experiments in which it was essential to identify carrier female $(T f m / T a)$, affected male $(T f m / Y)$, and normal male and female $(T a / Y$ and $T a / T a)$ offspring. In the remaining experiments animals were derived from matings between $T \mathrm{fm} / T a$ or $T \mathrm{fm} / \mathrm{X}$ females and normal BALB/c males $(\mathrm{X} / \mathrm{Y})$.

For studies of the effect of androgen administration on the differentiation of the male and female genital tracts, i.m. injections of dihydrotestosterone $(2 \mathrm{mg}$ dissolved in triolein) were begun between days 9 and 11 postcopulation and continued daily until delivery; after delivery, the newborn animals were given $0.2 \mathrm{mg}$ dihydrotestosterone subcutaneously every other day and were killed on day 10 .

To study the effects of ligation of the vas deferens and surgically induced cryptorchidism on testosterone synthesis in the testes, normal male littermates of $T f m$ mice were operated at 3 wk of age under ether anesthesia. After ligation of the vas deferens and/or suturing the testes to the abdominal wall, the animals were allowed to recover, and at $6 \mathrm{wk}$ of age the testes were removed for study. All other experiments were performed either on animals 2-5 days after birth or on animals that were between 6 and 8 wk of age as indicated.

Tissue slice studies. For the tissue slice studies, tissues were dissected shortly after death, stored in ice-cold KrebsRinger phosphate buffer, $\mathrm{pH} 7.4$, and combined for incubation experiments. In order to obtain adequate tissue for analyses, specimens from 2-4 newborn animals were combined for study. On the average about 60 min elapsed between the time of death and the beginning of the incubations. For the incubation studies tissue slices, approximately $0.2 \mathrm{~mm}$ thick, were prepared by hand and weighed on a tissue balance.

The method used for the assessment of rates of dihydrotestosterone formation in small amounts of tissue has been described in detail (20). The standard incubation mixture contained tissue slices (5-15 mg in weight), KrebsRinger phosphate buffer, $\mathrm{pH} 7.4$, testosterone-1,2- ${ }^{3} \mathrm{H} \quad(3.5 \times$ $10^{-8} \mathrm{M}$ containing $\left.9.5 \times 10^{5} \mathrm{cpm}\right)$, and glucose $\left(1.1 \times 10^{-2} \mathrm{M}\right)$ in a total volume of $1 \mathrm{ml}$. The tubes were gassed with 95\% oxygen-5\% carbon dioxide, capped, and incubated with shaking at $37^{\circ} \mathrm{C}$ for $2 \mathrm{hr}$. At the end of the incubation 
TABLE I

Recrystallization of Dihydrotestosterone- ${ }^{3} \mathrm{H}$ from Mouse Tissues*

\begin{tabular}{|c|c|c|c|c|c|c|c|c|c|c|}
\hline \multirow[b]{3}{*}{ Solvent } & \multicolumn{10}{|c|}{ Dihydrotestosterone- ${ }^{3} \mathrm{H}$ specific activity } \\
\hline & \multicolumn{7}{|c|}{ Adult } & \multicolumn{3}{|c|}{ Newborn } \\
\hline & $\begin{array}{c}\text { Epididymis } \\
\text { and } \\
\text { seminal } \\
\text { vesicle }\end{array}$ & Prostate & $\begin{array}{l}\text { Uterus } \\
\text { and } \\
\text { fallopian } \\
\text { tubes }\end{array}$ & Vagina & $\begin{array}{l}T f m \\
\text { urogenital } \\
\text { sinus }\end{array}$ & Bladder & Stomach & $\begin{array}{l}\text { Urogenital } \\
\text { sinus }\end{array}$ & Bladder & Stomach \\
\hline & \multicolumn{3}{|c|}{$c p m / m g$} & \multicolumn{4}{|c|}{$c p m / m g$} & \multicolumn{3}{|c|}{$c p m / m g$} \\
\hline Methanol & 828 & 524 & 438 & 211 & 151 & 740 & 292 & 300 & 452 & 114 \\
\hline Benzene + heptane & 819 & 504 & 286 & 199 & 108 & 500 & 88 & 253 & 43 & 52 \\
\hline Ethyl acetate + pentane & 868 & 680 & 305 & 291 & 143 & 275 & 41 & 268 & 37 & 19 \\
\hline Ethyl ether + heptane & 894 & 631 & 342 & 302 & 154 & 148 & 59 & 267 & 43 & 13 \\
\hline
\end{tabular}

* Material tentatively identified as dihydrotestosterone- ${ }^{3} \mathrm{H}$ was isolated by preparative thin-layer chromatography as described in the text, mixed with $100 \mathrm{mg}$ carrier steroid and recrystallized four times.

period the radioactive metabolites were extracted, chromatographed, and assayed as described (20). To establish the validity of these incubation conditions for mouse tissues, a series of recrystallization experiments were performed in which extracts from 3-5 different incubation mixtures were combined, and material tentatively identified as dihydrotestosterone $-{ }^{3} \mathrm{H}$ was isolated by preparative thin-layer chromatography, combined with carrier steroid, and recrystallized four times as described previously (21). In the case of urogenital tissues from adult and newborn animals of both sexes, the final specific activities of the crystals were similar to that of the starting material, as the result of which it was concluded that the thin-layer chromatographic system is valid for estimation of the rates of dihydrotestosterone formation in these tissues (Table I). In two tissues (bladder and stomach), however, some radioactive material chromatographed with dihydrotestosterone but was lost during recrystallization (this substance has been identified tentatively as androsterone), and the apparent rates of dihydrotestosterone formation for these two tissues were suitably corrected.

For studies of the rates of testosterone formation by slices of gonadal tissues, a preliminary series of experiments were performed to establish reliable conditions for this assay (Table II). Testosterone synthesis was shown to be reasonably linear with incubation time between 15 min and $2 \mathrm{hr}$ and to be linear with amounts of tissue slices that varied between $5 \mathrm{mg}$ and $20 \mathrm{mg}$ in weight. At substrate concentrations of pregnenolone-7 $\alpha^{3} \mathrm{H}$ and progesterone-1,2- ${ }^{3} \mathrm{H}$ that varied between $4 \times 10^{-7}$ and $2 \times 10^{-6} \mathrm{M}$ no plateau in testosterone formation was observed. The standard incubation mixture contained gonadal slices $(10 \mathrm{mg})$, Krebs-Ringer phosphate buffer, $\mathrm{pH} 7.4$, glucose $\left(1.1 \times 10^{-2}\right.$ M) and substrate (either pregnenolone- $7 \alpha_{-}{ }^{3} \mathrm{H}$, progesterone$1,2-{ }^{3} \mathrm{H}, \quad 17 \alpha$-hydroxy-progesterone $-1,2-^{3} \mathrm{H}$, or androstenedione-1,2- ${ }^{3} \mathrm{H}$ ) at a concentration of $1 \times 10^{-6}$ M (and containing $\left.2.5-5.0 \times 10^{7} \mathrm{cpm}\right)$ in a total volume of $1.0 \mathrm{ml}$. The latter concentration was chosen arbitrarily after a series of exploratory experiments because it allowed linear rates of synthesis without depletion of substrate during the incubation experiments. The tubes were gassed with $95 \% \quad \mathrm{O}_{2}-5 \% \quad \mathrm{CO}_{2}$ and incubated at $37^{\circ} \mathrm{C}$ for $1 \mathrm{hr}$ with shaking. At the end of the incubation the radioactive steroids were extracted with $4 \mathrm{ml}$ of chloroform: methanol (2:1). A $0.1 \mathrm{ml}$ portion of the chloroform: methanol extract (containing about $40,000 \mathrm{cpm}{ }^{3} \mathrm{H}$ ) was then com- bined with a carrier mixture of $10 \mu \mathrm{g}$ each of seven steroids, taken to dryness, and reconstituted in $25 \mu \mathrm{l}$ of chloroform. The sample was spotted for thin-layer chromatography on plates of silica gel $\mathrm{H}$ and developed in the cold in chloroform: methanol $(97: 3)$. The plates were airdried, stained, and assessed for radioactivity as previously described (22). As is illustrated in Fig. 1, this chromatographic system allows separation of a variety of metabolites that are intermediates in the conversion of pregnenolone to testosterone.

Evidence for the validity of this thin-layer chromatographic technique of assessing testosterone formation in slices of testis is demonstrated in Table III in which material tentatively identified as testosterone $-{ }^{3} \mathrm{H}$ after incubation of the slices with pregnenolone-7 $\alpha{ }^{3} \mathrm{H}$ or progesterone-1,2${ }^{3} \mathrm{H}$ was mixed with $200 \mathrm{mg}$ carrier testosterone and recrystallized four times. Since there was no significant decrease in the specific activity it was concluded that this

\section{TABLE II}

Establishment of Conditions for the Assessment of Testosterone Formation from Pregnenolone- $7 \alpha^{-3} \mathrm{H}$ and Progesterone$1,2-{ }^{3} \mathrm{H}$ by Slices of Mouse Testes

\begin{tabular}{ccccc}
\hline & & & \multicolumn{2}{c}{ Testosterone formation from } \\
\cline { 4 - 5 } Weight & Incubation & Substrate & Pregnenolone- & Progesterone- \\
of slices & time & concentration & $\begin{array}{c}\text { P } \boldsymbol{\alpha}^{-3} \mathrm{H} \\
1,2-{ }^{3} \mathrm{H}\end{array}$ \\
\hline$m g$ & & $M$ & $p m o l e s$ & $p m o l e s$ \\
10 & $1 \mathrm{hr}$ & $4 \times 10^{-7}$ & 77 & 68 \\
10 & $1 \mathrm{hr}$ & $8 \times 10^{-7}$ & 148 & 86 \\
10 & $1 \mathrm{hr}$ & $1.2 \times 10^{-6}$ & 192 & 233 \\
10 & $1 \mathrm{hr}$ & $1.6 \times 10^{-6}$ & 221 & 299 \\
10 & $1 \mathrm{hr}$ & $2.0 \times 10^{-6}$ & 286 & -38 \\
10 & $15 \mathrm{~min}$ & $1 \times 10^{-6}$ & 88 & 51 \\
10 & $30 \mathrm{~min}$ & $1 \times 10^{-6}$ & 123 & 121 \\
10 & $1 \mathrm{hr}$ & $1 \times 10^{-6}$ & 162 & 168 \\
10 & $2 \mathrm{hr}$ & $1 \times 10^{-6}$ & 229 & 52 \\
5 & $1 \mathrm{hr}$ & $1 \times 10^{-6}$ & 60 & 121 \\
10 & $1 \mathrm{hr}$ & $1 \times 10^{-6}$ & 162 & 139 \\
15 & $1 \mathrm{hr}$ & $1 \times 10^{-6}$ & 182 & 208 \\
20 & $1 \mathrm{hr}$ & $1 \times 10^{-6}$ & 229 &
\end{tabular}

Slices were incubated in Krebs-Ringer phosphate buffer, $\mathrm{pH}$ 7.4, containing glucose $\left(1.2 \times 10^{-2} \mathrm{M}\right)$ and substrate as indicated in a total volume of $1 \mathrm{ml}$. 


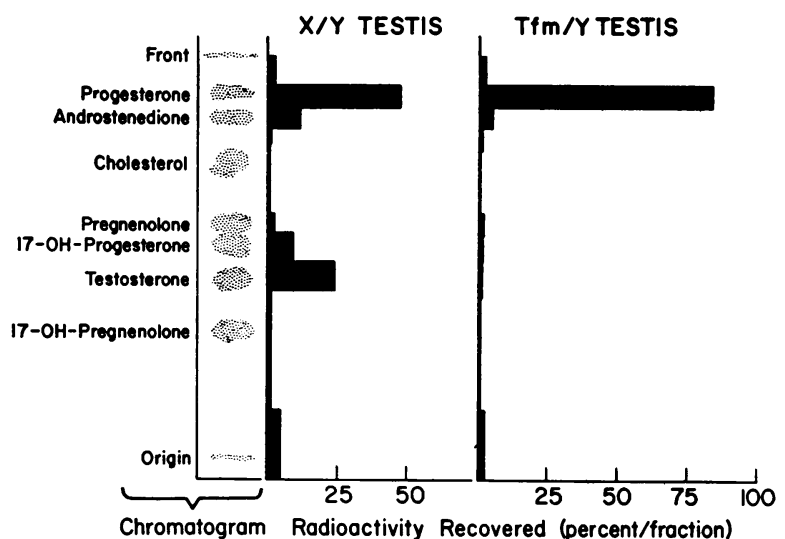

Figure 1 Separation by thin-layer chromatography of the metabolites of progesterone-1,2- ${ }^{3} \mathrm{H}$ after incubation with slices of testes. Slices of adult testes $(15 \mathrm{mg})$ were incubated with progesterone-1,2- ${ }^{3} \mathrm{H} \quad\left(1 \times 10^{-8}\right.$ M containing $\left.5 \times 10^{7} \mathrm{cpm}\right)$, glucose $\left(1.1 \times 10^{-2} \mathrm{M}\right)$ and Krebs-Ringer

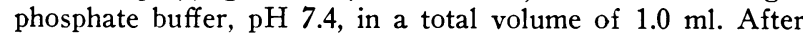
incubation for $1 \mathrm{hr}$ at $37^{\circ} \mathrm{C}$, the steroids were extracted into chloroform: methanol $(2: 1)$, and portions were spotted on thin-layer chromatograph plates. The plates were developed in chloroform: methanol $(97: 3)$, sprayed with anisaldehyde, scraped into counting vials, and assayed for radioactivity.

separation does provide a suitable means for the assessment of testosterone formation in mouse testes. For the assessment of rates of conversion the percentage of the total radioactivity recovered in the testosterone area was multiplied by the amount of substrate steroid added to the original mixture.

Intranuclear localization studies. For studies of the intranuclear localization of radioactive testosterone the mice were subjected to functional hepatectomy under ether anesthesia using the technique described by Hotta and Chaikoff (23). Some animals were subjected to castration 1-2 weeks

\section{TABLE III}

Recrystallization of Testosterone- ${ }^{3} \mathrm{H}$ from Mouse Testes Incubated with Progesterone-1,2- ${ }^{3} \mathrm{H}$ and Pregnenolone- $7 \alpha{ }^{3} \mathrm{H}$

\begin{tabular}{|c|c|c|c|c|}
\hline \multirow[b]{3}{*}{ Solvent } & \multicolumn{4}{|c|}{$\begin{array}{l}\text { SA of testosterone-3} \mathrm{H} \text { recovered after } \\
\text { incubation of testes with }\end{array}$} \\
\hline & \multicolumn{3}{|c|}{ Pregnenolone $-7 \alpha-{ }^{3} \mathrm{H}$} & \multirow{2}{*}{$\begin{array}{c}\text { Progesterone- } \\
1,2-{ }^{-3} \mathrm{H} \\
\begin{array}{c}\text { Normal } \\
\text { adult } \\
\text { testes }\end{array}\end{array}$} \\
\hline & $\begin{array}{c}\text { Normal } \\
\text { newborn } \\
\text { testes }\end{array}$ & $\begin{array}{c}T f m \\
\text { newborn } \\
\text { testes }\end{array}$ & $\begin{array}{c}\text { Normal } \\
\text { adult } \\
\text { testes }\end{array}$ & \\
\hline & \multicolumn{3}{|c|}{$c p m / m g$} & $c p m / m g$ \\
\hline Methanol & 380 & 1050 & 3820 & 5200 \\
\hline Benzene + heptane & 460 & 1130 & 4000 & 4910 \\
\hline Ethyl acetate + pentane & 420 & 1300 & 4300 & 4630 \\
\hline Ethyl ether + heptane & 500 & 1320 & 4600 & 5082 \\
\hline
\end{tabular}

* Material tentatively identified as testosterone- ${ }^{3} \mathrm{H}$ was isolated by preparative thin-layer chromatography, mixed with $200 \mathrm{mg}$ carrier testosterone and recrystallized four times. before study, and some received $2 \mathrm{mg}$ testosterone in oil every other day for 7-10 days before death. In a preliminary series of experiments it was found to be necessary in this procedure to ligate the hepatic artery; otherwise, almost no unmetabolized testosterone could be recovered from the blood at the end of $1 \mathrm{hr}$. Testosterone- $1,2{ }^{3} \mathrm{H}$ (50 $\mu \mathrm{Ci}$ dissolved in saline as described previously (22)) was administered i.v. The animals were killed $1 \mathrm{hr}$ later, and the submandibular glands were removed, carefully dissected free of connective tissue, sliced into small pieces by hand with a razor blade, and homogenized with 10 vol of $0.88 \mathrm{M}$ sucrose-1.5 $\mathrm{mm} \mathrm{CaCl} \mathrm{Ca}_{2}$ in a specially constructed micro Dounce homogenizer with 20 strokes of the plunger. The homogenates were filtered through cheese cloth, and nuclei were isolated by a micromodification of the Chauveau procedure (24). The homogenates were centrifuged at $800 \mathrm{~g}$; the pellets from this centrifugation were rehomogenized in $4.5 \mathrm{ml} 2.0 \mathrm{M}$ sucrose $-0.5 \mathrm{mM} \mathrm{CaCl}{ }_{2}$ and centrifuged at $63,000 \mathrm{~g}(23,000 \mathrm{rpm})$ in a SW 39.1 rotor for $60 \mathrm{~min}$. The pellet was rehomogenized in $2.0 \mathrm{M}$ sucrose- $0.5 \mathrm{~mm}$ $\mathrm{CaCl}_{2}$ and centrifuged again for $1 \mathrm{hr}$ at $63,000 \mathrm{~g}$. The pellet from this second centrifugation was suspended in 0.88 is sucrose and assayed for radioactivity and DNA, as were the starting homogenates. By light microscopy (21) these nuclei were $97 \%$ pure, the remainder consisting of occasional whole cells or nuclei with large cytoplasmic tags. In a preliminary series of experiments $1 \mathrm{hr}$ was shown to provide better recovery of nuclear radioactivity than $30 \mathrm{~min}$ or $1 \frac{1}{2} \mathrm{hr}$, and concentrations of sucrose greater than $2.0 \mathrm{M}$ were shown to result in small yields of recovered DNA in the nuclear pellet. DNA was measured by the diphenylamine method of Burton (25), using salmon sperm DNA as the standard. In one study the nuclei from several experiments were pooled, and the radioactive steroids were extracted into chloroform: methanol, subjected to thin-layer chromatography and assayed for ${ }^{3} \mathrm{H}$ as before.

Blood hormone assays. Blood was collected from the inferior vena cava of anesthetized animals. The serum from 2-5 animals was separated, pooled, and frozen for subsequent studies. Serum luteinizing hormone was assayed by Doctors Robert Eskay and John Porter using a radioimmunoassay technique and NIAMD Rat LH-RP-I (National Institute of Arthritis and Metabolic Diseases) as the reference standard. Serum testosterone assay was performed by the Inter Science Institute, Los Angeles, Calif., utilizing a protein binding method, without knowledge of the identity of individual samples.

Materials. Dihydrotestosterone was obtained from Steraloids, Inc., Pawling, N. Y. Male BALB/c and Tabby mice were purchased from the Jackson Memorial Laboratory, Bar Harbor, Maine. The various radioactive steroids (testosterone $-1,2-{ }^{3} \mathrm{H} \quad(5 \mathrm{mCi} / 32 \mu \mathrm{g})$, pregnenolone- $7 \alpha-{ }^{3} \mathrm{H} \quad(5$ $\mathrm{mCi} / 68.5 \mu \mathrm{g})$, progesterone-1,2- ${ }^{3} \mathrm{H}(5 \mathrm{mCi} / 32.5 \mu \mathrm{g}), 17 \alpha-$ hydroxyprogesterone $(5 \mathrm{mCi} / 33.6 \mu \mathrm{g})$, and androstenedione$1,2-{ }^{3} \mathrm{H}(5 \mathrm{mCi} / 28.5 \mu \mathrm{g})$ were purchased from the New England Nuclear Corp., Boston, Mass., and were demonstrated to be at least $95 \%$ pure by thin-layer chromatography before use.

\section{RESULTS}

Identification of the phenotypes in the newborn. To determine whether the testicular feminization phenotype could be identified in newborn animals, a series of dissections were performed in animals 2 days of age. As is illustrated in the photographs of whole mounts of the 
mouse urogenital tracts in Fig. $2 A$, in newborn mice three phenotypes can easily be distinguished-female, male, and Tfm; the Tfm animal has a distinct testis but lacks the accessory organs of male reproduction (the epididymis, vas deferens, seminal vesicle, and prostate), which are replaced with strands of fibrous connective tissue. It has not been possible to distinguish between carrier $(T f m / X)$ and normal $(\mathrm{X} / \mathrm{X})$ females on the basis of dissection of the urogenital tracts either at this age or later; however in offspring of $T a / \mathrm{Y}$ males and $T \mathrm{fm} / \mathrm{Ta}$ females it is possible to distinguish between the $T f m / T a$ and $T a / T a$ offspring since the $T a / T a$ phenotype in the mouse is manifest clearly by day 3 (26).

Characterization of the hormonal status of the Tfm mouse. It has been reported that the rat with inherited male pseudohermaphroditism (27), in contrast to the testicular feminization syndrome in man $(9,28,29)$, has a defect in testosterone biosynthesis and low testosterone blood levels. Since early castration in the rat has been reported to lead to a variety of secondary changes, including partial androgen insensitivity $(30,31)$, it was necessary to characterize the hormonal status of the $T f m$ mice. Therefore, testosterone values were compared in pooled samples of serum from normal male, normal female and $T \mathrm{fm}$ mice, all between 6 and 8 wk of age (Fig. 3). The average serum testosterone value in normal male animals was $800 \pm 150 \mathrm{ng} / 100 \mathrm{ml}( \pm 2 \mathrm{sEM})$, and that in normal females was $50 \pm 10 \mathrm{ng} / 100 \mathrm{ml}( \pm 2 \mathrm{sEM})$; in $T f m$ animals the concentration was intermediate between that of males and females, averaging $150 \pm 100 \mathrm{ng} / 100 \mathrm{ml}( \pm 2$ SEM), a value which was on an average distinctly lower than in the normal male and in some animals in the castrate range. In keeping with low circulating testosterone values was the finding that serum $\mathrm{LH}$ concentration in the $T f m$ rat was higher (averaging $470 \mathrm{ng} / \mathrm{ml}$ serum) than in normal male littermates (averaging 160 $\mathrm{ng} / \mathrm{ml}$ serum ).

Evidence that the abnormality in the circulating levels of testosterone is secondary to a defect in testosterone synthesis is summarized in Fig. 4 in which testosterone formation from four precursors was compared in tissue slices of male, female, and $T f m$ gonads from animals 6-8 wk of age. In each instance, testosterone formation was low in the tissues from the Tfm animals; furthermore, if the average rates of biosynthesis per unit weight are projected to the weight of the entire organ (averaging $80 \mathrm{mg}$ per testis in the normal male and $9 \mathrm{mg}$ per testis in the Tfm), it is apparent that the testis from the $T f m$ animal has a profound defect in testosterone biosynthesis. It is also striking that the defective synthesis is almost equally low from all four precursors studiedandrostenedione, $17 \alpha$-hydroxyprogesterone, progesterone, and pregnenolone.
That the defect in testosterone biosynthesis, however, is not a primary defect in this mutation is suggested by the findings reported in Fig. 5, for clearly the testis from the newborn $T f m$ mouse has a normal capacity to synthesize testosterone from pregnenolone as compared with the testis from normal male animals. This finding implies that the capacity for testosterone formation may be normal at birth and that the subsequent failure in this capacity is an indirect consequence of some other defect.

The possibility was then investigated that the failure of testosterone biosynthesis in these animals might in part be the result either of the inevitable cryptorchidism that occurs in this condition or the fact that the excretory ducts are atrophic. As shown in Table IV, testosterone biosynthesis and testicular weight were assessed in normal males, Tfm animals, and littermate males that had been subjected to vas duct ligation and/or made surgically cryptorchid at $3 \mathrm{wk}$ of age. Neither surgical cryptorchidism nor vas duct ligation resulted in a significant decrease in the capacity for testosterone biosynthesis as compared with the normal animal, but a significant retardation in growth of the testes resulted from these procedures. It was concluded that the inability of the testis to form testosterone at a normal rate in the $T f m$ animal cannot be explained by these anatomical abnormalities and may well be the result of some loss in the capacity of the testes to grow in response to androgen (32).

Androgen resistance during sexual differentiation. In order to establish with certainty that deficient androgen synthesis does not play a role in the failure in differentiation of male internal and external genitalia in this

TABLE IV

Effect of Vas Duct Ligation and Cryptorchidism on Testicular Weight and Testosterone Biosynthesis in Mouse Testes

\begin{tabular}{|c|c|c|c|c|}
\hline Group & Animals & Operation & $\begin{array}{c}\text { Mean } \\
\text { weight } \\
\text { of } \\
\text { testes }\end{array}$ & $\begin{array}{c}\text { Testosterone } \\
\text { formation } \\
\text { from } \\
\text { pregnenolone- } \\
7 \alpha_{-s} \mathrm{H}\end{array}$ \\
\hline & & & $m g$ & $\begin{array}{c}\text { pmoles } / 10 \\
m g / h r \pm \mathrm{SEM}\end{array}$ \\
\hline 1 & Male (12) & None & 90.4 & $187.8 \pm 15.4$ \\
\hline 2 & $T f m$ & None & 10.1 & $15.0 \pm 5.2$ \\
\hline 3 & Male (7) & $\begin{array}{c}\text { Vas duct } \\
\text { ligation }\end{array}$ & 94.6 & $155.0 \pm 14.2$ \\
\hline 4 & Male (4) & Cryptorchid & 49.8 & $146.5 \pm 18.5$ \\
\hline 5 & Male (4) & $\begin{array}{l}\text { Vas duct } \\
\text { ligation plus } \\
\text { cryptorchid }\end{array}$ & 30.0 & $124.0 \pm 69.5$ \\
\hline
\end{tabular}

The animals were operated at $3 \mathrm{wk}$ of age, and the experiments were performed at $6 \mathrm{wk}$ of age. The number of animals in each experiment is shown in parentheses.

Male Pseudohermaphroditism in the Mouse 


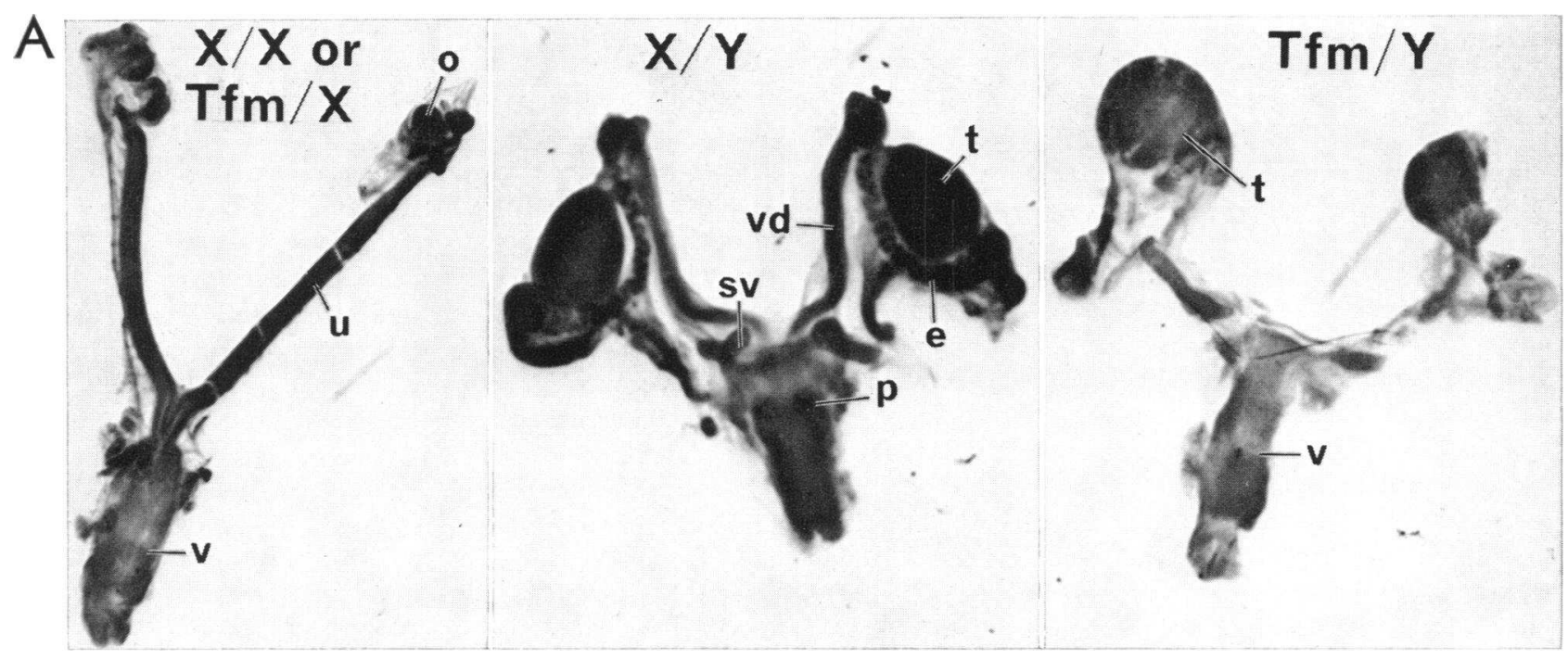

B $\quad X / X$
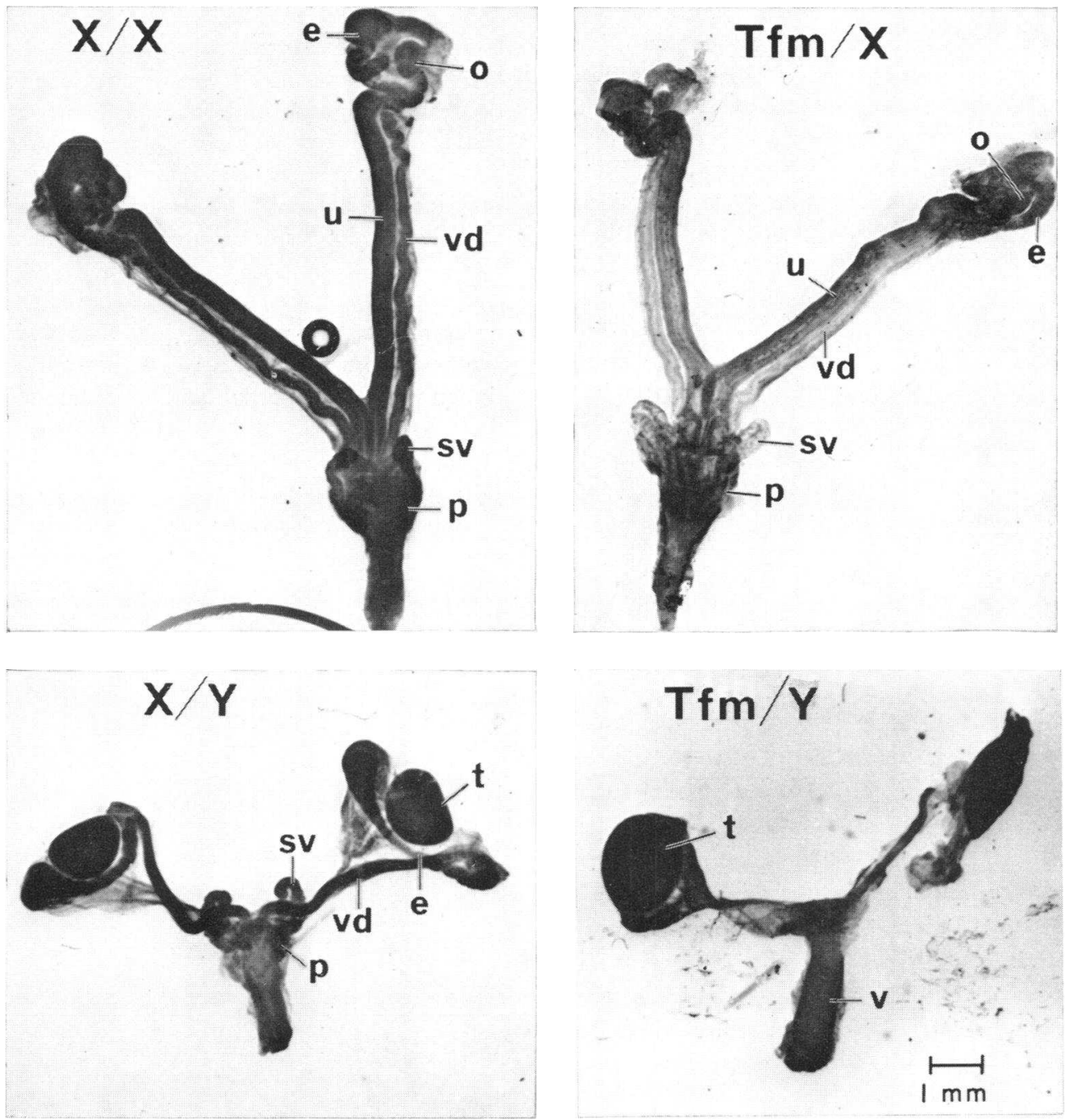

1652 J. L. Goldstein and J. D. Wilson 
TABLE V

Effect of Dihydrotestosterone on the Development of the Epididymis, Seminal Vesicles, and Prostate in the Mouse Embryo

\begin{tabular}{|c|c|c|c|}
\hline \multirow[b]{2}{*}{ Genotype } & \multirow[b]{2}{*}{$\begin{array}{c}\text { Total } \\
\text { number } \\
\text { of } \\
\text { animals }\end{array}$} & \multicolumn{2}{|c|}{ Animals with } \\
\hline & & $\begin{array}{l}\text { Masculine } \\
\text { Wolffian } \\
\text { duct and } \\
\text { urogenital } \\
\text { sinus }\end{array}$ & $\begin{array}{c}\text { Intact } \\
\text { Mullerian } \\
\text { system }\end{array}$ \\
\hline$T a / Y$ & 4 & 4 & $\mathbf{0}$ \\
\hline$T f m / Y$ & 3 & $\mathbf{0}$ & 0 \\
\hline$T a / T a$ & 5 & 5 & 5 \\
\hline$T a / T f m$ & 2 & 2 & 2 \\
\hline
\end{tabular}

Dihydrotestosterone dissolved in oil $(2 \mathrm{mg})$ was administered subcutaneously to pregnant animals beginning 9-11 days postcopulation and continued until delivery; after delivery the newborn were given $0.2 \mathrm{mg}$ dihydrotestosterone subcutaneously every other day and were killed on day 10 . Photographs of whole mounts of the urogenital tracts of four of the animals are shown in Fig. $2 B$.

condition, a series of experiments were performed in which dihydrotestosterone was administered to pregnant carrier females $(T f m / T a)$ that had been mated to $T a / Y$ males, beginning on the 9-11th day postcopulation and continuing up until 10 days after birth of the animals (Fig. $2 B$ and Table V). Since virilization of the male fetus in the mouse does not begin until day 13 (12), such treatment should result in virilization of female embryos. As is illustrated in Fig. $2 B$, both the female $(T a / T a)(\mathrm{X} / \mathrm{X}$ in Fig. $2 B)$ and carrier $(T f m / T a)$ $(T f m / X$ in Fig. $2 B)$ offspring exhibited striking virilization, including male development of the Wolffian duct into epididymis, vas deferens, and seminal vesicle and the development of a prostate. As would be expected from the studies of Jost (11), such androgen treatment did not cause Mullerian regression in these animals and may have actually stimulated its development (13). The male urogenital tract appears normal, whereas there is no evidence of virilization of the $T \mathrm{fm}$ urogenital tract in comparison with the untreated specimens shown in Fig. $2 A$. This study was interpreted as providing the first direct experimental proof of the view (8) that the failure of male sexual differentiation in the testicular feminization syndrome is due to androgen resistance during embryogenesis.

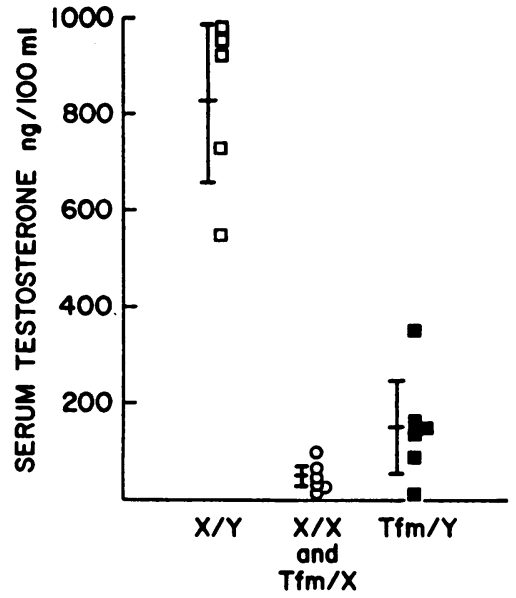

Figure 3 Serum testosterone in male, female, and $T f m$ mice. Serum from four to six 6-8 wk old mice was pooled for each assay. The bars represent mean values \pm 2 SEM.

Dihydrotestosterone formation in the Tfm animal. The next aspect of testosterone action that was examined was the conversion of testosterone to dihydrotestosterone, the testosterone metabolite that has been postulated to be the active intracellular androgen both for certain testosterone mediated functions in the adult $(21,33)$ and for some aspects of sexual differentiation in embryos as well (20). As is clearly demonstrated in Fig. 6, the rate of dihydrotestosterone formation in the tissues of the normal adult male mouse is similar to that previously reported in the rat, namely high rates of formation in the male organs of accessory reproduction-the epididymis, seminal vesicle, prostate, and phallus-and low rates in the remaining tissues (34). In adult normal and carrier females, however, the rates of formation are low in all tissues other than for the Fallopian tubes and uterus and the external genitalia. In the adult $T f m$ animal, the pattern of formation resembles closely that of the female animal. However, it is clear that it is impossible to assess the importance of this formation properly under conditions in which the tissues in question such as epididymis, prostate, and seminal vesicles have failed to develop. To attempt to determine whether the failure of male differentiation was the cause rather than the result of deficient dihydrotestosterone formation, therefore, dihydrotestosterone formation was assessed in tis-

FIGURE 2 Whole mounts of dissected urogenital tracts of infant normal and $T f m$ mice. $(A)$ Control mice. Dissections were performed 3 days after delivery. (B) Dihydrotestosteronetreated mice. Dihydrotestosterone ( $2 \mathrm{mg} / \mathrm{day}$ ) was administered to pregnant animals beginning 9 days postcopulation, and after delivery the newborn were given dihydrotestosterone $(0.2 \mathrm{mg}$ every other day). The animals were killed and dissected on day 10. The results of studies in 14 animals so treated are summarized in Table V. o, ovary; u, uterus; v, vagina; $t$, testis; vd, vas deferens; sv, seminal vesicle; e, epididymis; p, prostate. 


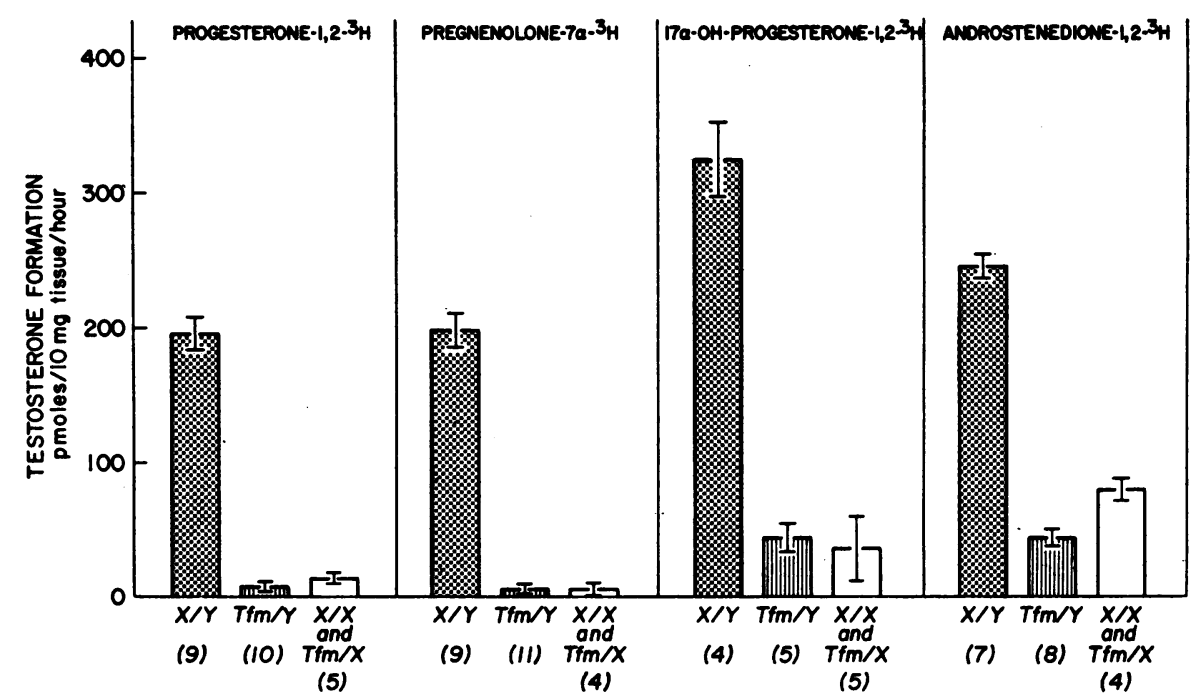

Figure 4 Testosterone formation from progesterone, pregnenolone, $17 \alpha$-OH-progesterone, and androstenedione by slices of normal mouse testes and ovaries and of testes from $T f m$ mice. 6-8 wk old animals were used for these experiments. The figures in parentheses indicate the number of experiments, and the bars represent mean values \pm 1 SEM.

sues of newborn animals (Fig. 7). In these tissues, there was no difference between male and $T f m$ animals in the rates of formation of dihydrotestosterone in the urogenital sinus, the urogenital tubercle, or the Wolffian ducts, which represent the embryologic anlage of the prostate, the external genitalia, and the epididymis and seminal vesicles respectively. Clearly in the $T f m$ mouse, deficient dihydrotestosterone formation is a result rather than the cause of the male pseudohermaphroditism.

Intranuclear localization of testosterone in the submandibular gland. In order to determine whether the re-

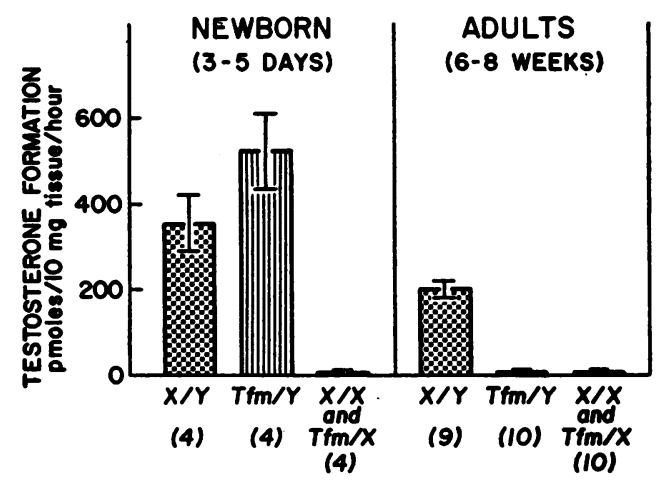

FIGURE 5 Comparison of the ability of newborn and adult testes to convert pregnenolone- $7 \alpha-{ }^{8} \mathrm{H}$ to testosterone. The incubation conditions are described in the text and in Fig. 1. The figures in parentheses indicate the number of experiments, and the bars indicate the mean value \pm 1 SEM. ported defect in the intranuclear localization of testosterone in the kidney of the adult $T f m$ animal $(18,19)$ was a university aspect of this disorder, the intracellular localization of testosterone-1,2- ${ }^{3} \mathrm{H}$ was assessed in the submandibular gland, a tissue in which secretion is testosterone-dependent (35-37) and in which the testosteronemediated secretion of nerve growth factor in the $T f m$ animal is deficient. ${ }^{2}$ As is shown in Table VI the intranuclear localization of radioactivity in submandibular gland nuclei following the administration of testosterone$1,2-{ }^{3} \mathrm{H}$ was compared in the nuclei of normal, testosterone-treated, and castrated animals. The uptake of radioactivity by the glands in male, female, and $T f m$ animals was similar, but there was a significant difference between the male and female mice and the $T f m$ animals in the nuclear uptake, both in the gross recovery of radioactivity in the nuclear preparations and the recovery of radioactivity when corrected for the percentage of total DNA recovered in the purified nuclei fraction. Nuclear preparations from six experiments were pooled, and the steroids were extracted into chloroform: methanol $(2: 1)$ and chromatographed by thin-layer chromatography. In nuclei from male and female animals, $76 \%$ of the recovered radioactivity corresponded to testosterone and $9 \%$ to dihydrotestosterone, and in the nuclei from the $T \mathrm{fm}$ animals $36 \%$ of the recovered ${ }^{3} \mathrm{H}$ corresponded to testosterone and $23 \%$ to dihydrotestosterone; the remainder of

\footnotetext{
${ }^{2}$ Lyon, M. F. Personal communication.
} 


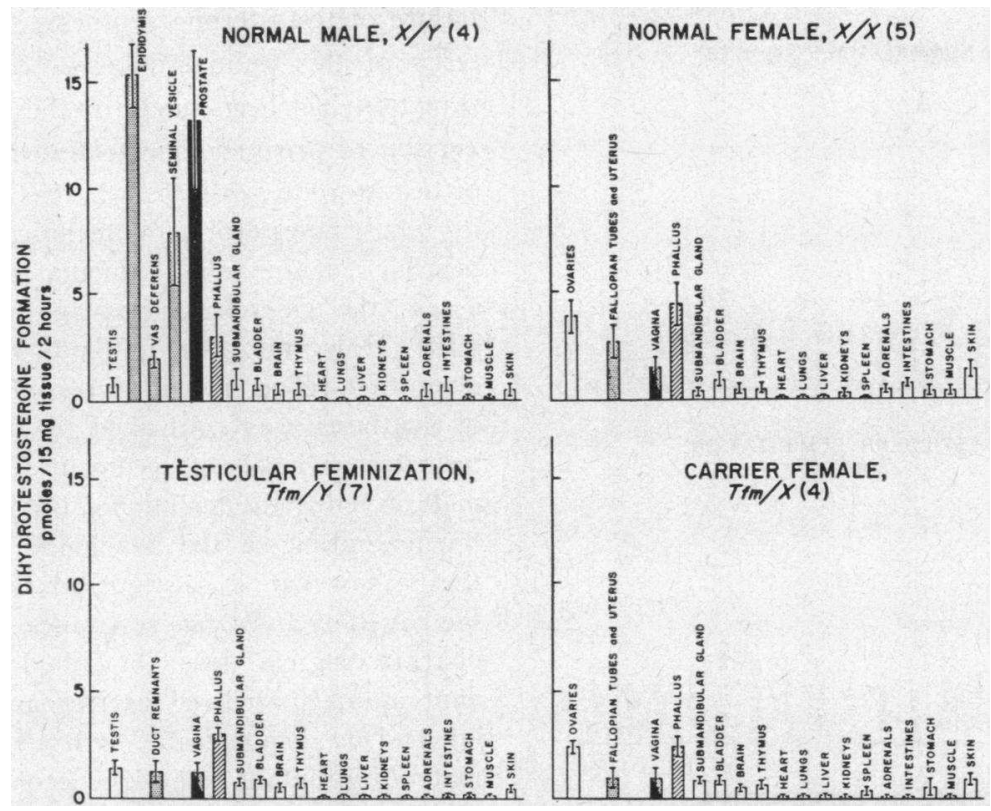

Figure 6 Dihydrotestosterone formation by tissue slices from adult mice. The standard incubation mixture contained tissue slices $(5-15 \mathrm{mg})$, Krebs-Ringer phosphate buffer, $\mathrm{pH}$ 7.4, testosterone-1,2-3 $\mathrm{H}\left(3.5 \times 10^{-8} \mathrm{M}\right)$, and glucose $\left(1.1 \times 10^{-2} \mathrm{M}\right)$ in a total volume of $1 \mathrm{ml}$. After incubation for $2 \mathrm{hr}$. at $37^{\circ} \mathrm{C}$, the steroids were extracted, chromatographed, and analyzed for radioactivity as described in the text. The stippled bars indicate tissues which were derived from the embryonic Mullerian or Wolffian ducts, the solid black bars tissues derived from the embryonic urogenital sinus.

the radioactivity in each case was spread uniformly across the plates. These experiments were interpreted as confirming the recent reports of defective intranuclear binding of androgen in kidney nuclei $(18,19)$ and are compatible with the possibility that such a defect may be primary in this condition.

TABLE VI

Intracellular Localization of Testosterone-1,2-3 $\mathrm{H}$ in Submandibular Glands of Functionally Hepatectomized Mice

\begin{tabular}{|c|c|c|c|c|c|c|c|c|c|}
\hline \multirow[b]{3}{*}{ Group } & \multirow[b]{3}{*}{ Treatment } & \multirow{3}{*}{$\begin{array}{l}\text { Number } \\
\text { of experi- } \\
\text { ments }\end{array}$} & \multirow{3}{*}{$\begin{array}{c}\text { Average } \\
\text { subman- } \\
\text { dibular } \\
\text { gland } \\
\text { weight }\end{array}$} & \multirow{2}{*}{\multicolumn{2}{|c|}{ Average DNA recovery }} & \multicolumn{4}{|c|}{${ }^{2} \mathrm{H}$ recovery } \\
\hline & & & & & & \multirow{2}{*}{$\begin{array}{c}\text { Whole } \\
\text { homogenate }\end{array}$} & \multirow[b]{2}{*}{ Nuclei } & \multirow[b]{2}{*}{ Nuclei } & \multirow{2}{*}{$\begin{array}{c}\text { Nuclei } \\
\% \text { 'H/DNA } \\
\text { recovery } \\
\times 100\end{array}$} \\
\hline & & & & homogenate & Nuclei & & & & \\
\hline & & & $m g$ & $m g / o r g a n$ & $\%$ & $c p m \times 10^{-6}$ & $c p m$ & $\%$ & \\
\hline \multirow[t]{3}{*}{ Male } & None & 4 & 132 & 0.317 & 45.6 & $6.3 \pm 0.7$ & $8350 \pm 2500$ & $1.4 \pm 0.3$ & $3.1 \pm 0.6$ \\
\hline & Castration & 4 & 96 & 0.419 & 25.0 & $5.5 \pm 0.1$ & $7710 \pm 940$ & $1.4 \pm 0.2$ & $5.7 \pm 0.6$ \\
\hline & Testosterone & 2 & 155 & 0.351 & 30.4 & 7.8 & 6820 & 0.9 & 2.8 \\
\hline \multirow[t]{3}{*}{ Female } & None & 4 & 105 & 0.295 & 24.6 & $7.1 \pm 0.4$ & $4440 \pm 760$ & $0.6 \pm 0.1$ & $2.9 \pm 0.6$ \\
\hline & Castration & 4 & 88 & 0.334 & 24.4 & $7.0 \pm 0.9$ & $5828 \pm 1160$ & $0.9 \pm 0.2$ & $4.5 \pm 1.7$ \\
\hline & Testosterone & 3 & 87 & 0.330 & 22.7 & 5.7 & 5520 & $1.0 \pm 0.2$ & 5.7 \\
\hline \multirow[t]{3}{*}{$T f m$} & None & 4 & 111 & 0.448 & 40.3 & $6.5 \pm 0.8$ & $800 \pm 370$ & $0.2 \pm 0.0$ & $0.4 \pm 0.3$ \\
\hline & Castration & 4 & 98 & 0.417 & 33.7 & $5.9 \pm 0.6$ & $1184 \pm 390$ & $0.1 \pm 0.0$ & $0.6 \pm 0.2$ \\
\hline & Testosterone & 3 & 104 & 0.256 & 19.0 & 5.0 & 1280 & 0.2 & 1.2 \\
\hline
\end{tabular}

6-8-wk old mice were functionally hepatectomized and given $50 \mu \mathrm{Ci}$ testosterone-1,2- ${ }^{3} \mathrm{H}$ i.v. $1 \mathrm{hr}$ later the animals were killed, and the submandibular glands from two animals were pooled, homogenized, and subjected to differential centrifugation as described in the text. Some animals were castrated 1-2 wk before study, and in some cases $2 \mathrm{mg}$ testosterone in oil was administered i.m. every other day for 7-10 days before death. The \pm figures indicate \pm SEM. 


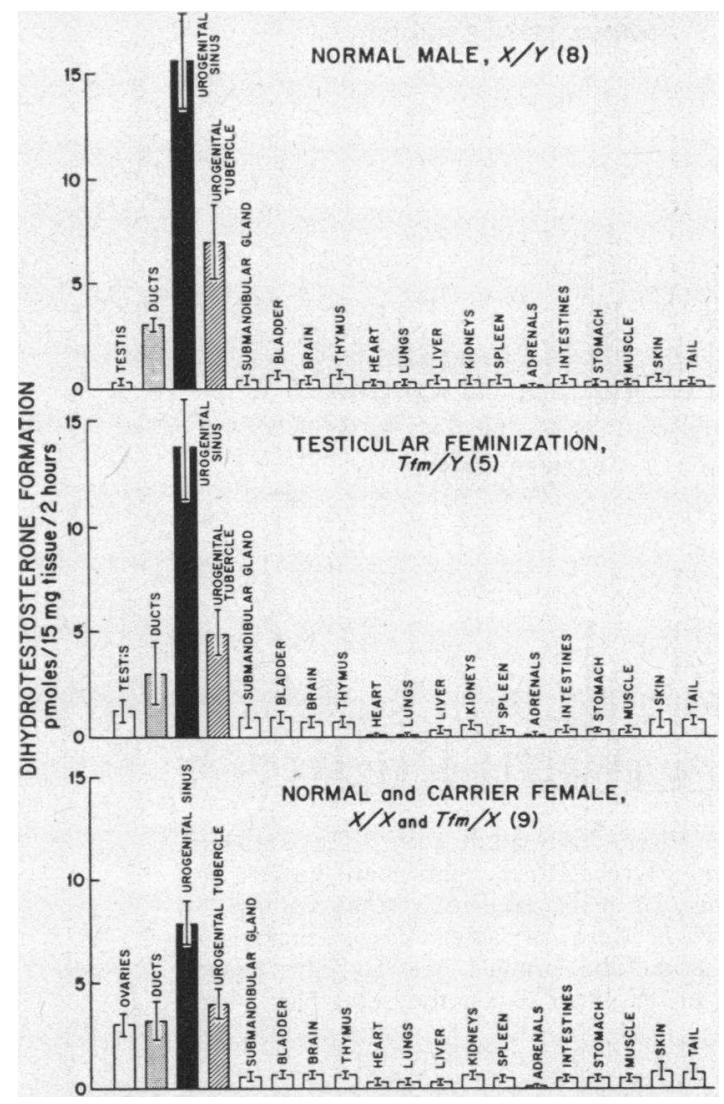

Figure 7 Dihydrotestosterone formation by tissue slices from newborn mice. The incubation conditions are described in Fig. 6 and the text.

\section{DISCUSSION}

On theoretical grounds male pseudohermaphroditism can be the result of defects at any of several critical steps in androgen action in the fetus-a failure of testosterone biosynthesis by the fetal testis, an inability to convert testosterone to dihydrotestosterone or other active androgen within the target cells, defective binding of androgens to cellular receptors, or some other defect in the ability of cells to respond to androgenic stimulus. The studies reported here in newborn and adult $\mathrm{Tfm}$ mice clearly establish that the failure of differentiation of the male accessory organs of reproduction in this mutation cannot be the consequence either of defective androgen synthesis or of diminished dihydrotestosterone formation but must instead be the result of a defect in some later aspect of androgen action.

Indeed, these findings suggest that two striking features of the $T f m$ syndrome in the adult mouse-namely deficient testosterone biosynthesis and diminished conversion of testosterone to dihydrotestosterone-are secondary consequences of some other primary defect. The failure of testosterone synthesis that occurs in the adult testis of this animal deserves comment. First, the assumption has been made in these studies that the conversion of pregnenolone to testosterone is a valid index of testosterone synthesis whereas the initial precursor is, in fact, cholesterol; for technical reasons, it was not possible in the small amount of tissues available to assess the side-chain cleavage reaction of cholesterol (38). However, it seems likely that the latter reactions do in fact reflect the in vivo conditions since the failure of synthesis was confirmed by measurements of actual testosterone levels of serum in affected and normal animals. Even if the techniques used here do underestimate the magnitude of the deficiency in testosterone biosynthesis, however, it is still clear that such a defect is not the cause of androgen resistance since administration of pharmacological doses of dihydrotestosterone to pregnant animals virilized carrier and normal female mice but had no demonstrable androgenic effect on the littermate Tfm mutant embryos. Second, the failure in testosterone biosynthesis and growth of the adult testis is probably not the consequence of cryptorchidism in these animals and must be the result of some other defect since it is not present in the newborn animal. Thus, the defect in the rat and mouse is different than in the human variety of testicular feminization, in which both testicular size and testosterone secretory rates are normal in the adult $(9,28,29,39)$. Third, it is not possible at present to assign the defect of testosterone biosynthesis to a specific enzymatic defect in the biosynthetic pathway for testosterone, since the rate of formation was uniformly depressed for all substrates tested and since no consistent pattern of accumulation of intermediates was observed in the tissue slice studies. Since the enzymes that are involved in the conversion of pregnenolone to testosterone are thought to exist in a distinctive microsomal unit (38), the possibility exists that this enzyme package has been lost symmetrically in the $T f m$ testes. Finally, it is striking that testosterone biosynthesis is diminished under circumstances in which the Leydig cells have been said to be hypertrophic (6). This apparent discrepancy is probably due to at least three factorsthe remarkably small size of the $T f m$ testis, the fact that underdevelopment of the tubules may cause an apparent rather than a real increase in number of Leydig cells per testis, and finally the fact that in the rodent testis testosterone biosynthesis from pregnenolone may not take place exclusively in the Leydig cells (40).

The findings in the present study that dihydrotestosterone formation was normal in the anlage of the male organs of accessory reproduction at birth may have implications for the interpretation of the pathogenesis of the human variety of the disease, where it has been reported that dihydrotestosterone formation is deficient 
in the perineal skin and other tissues (14-16). On the basis of the present study it is clear that deficient dihydrotestosterone formation in human testicular feminization could result either from a defect that involves primarily the enzyme that performs this conversion or from a developmental defect that prevents the differentiation of the cell lines that contain this enzymatic function. Furthermore, the finding that dihydrotestosterone formation was normal in the newborn urogenital sinus in the $T f m$ animal despite a total lack of androgen effect on this tissue is strong confirmation of the previous conclusion in the embryos of rats, rabbits, and guinea pigs that the ability to form dihydrotestosterone by the $5 \alpha$-reductase enzyme system is an inherent capacity of this tissue, rather than induced by the action of fetal androgen $(20,41)$. The finding in the present studies that the rate of dihydrotestosterone formation is lower in the normal newborn Wolffian ducts than in the normal adult is also in keeping with the view that this enzymatic capacity is acquired during the development of the tissues derived from the Wolffian duct, namely the seminal vesicles and the epididymis $(20,41)$.

The demonstration in these studies of diminished intranuclear binding of testosterone in the nuclei of the submandibular gland of the adult $T \mathrm{fm}$ animals, together with the previous reports of Gehring, Tomkins, and Ohno (18) and Bullock, Bardin, and Ohno (19) that defective nuclear retention of androgen occurs in the kidney of the adult $T f m$ mouse, raise the possibility that the fundamental defect in androgen action in this abnormality involves an interaction between hormone and receptor sites. An alternative interpretation of these data is that the abnormalities observed in androgen binding in adult $T f m$ tissues do not represent the primary action of the mutant $T f m$ gene but are an example of another acquired, secondary abnormality of the testicular feminization syndrome in the adult. The resolution of this important issue will require the development of a highly sensitive method for assessing directly the ontogeny of androgen receptors in sexually differentiating tissues of the mouse embryo.

\section{ACKNOWLEDGMENTS}

James E. Unger, Mary B. Neal, and Frances E. York have provided able technical assistance in the performance of these studies.

This work has been aided by Grant AM3892 from the National Institutes of Health.

\section{REFERENCES}

1. Morris, J. M. 1953. The syndrome of testicular feminization in male pseudohermaphroditism. Amer. J. Obstet. Gynecol. 65 : 1192.

2. Nes, N. 1966. Testikulaer feminiseniz has storfe. Nord. Vet. Med. 18 : 19.
3. Schultz, M. G. 1962. Male pseudohermaphroditism diagnosed with aid of sex chromatin technique. J. Amer. Vet. Med. Ass. 140: 241.

4. Stanley, A. J., and L. G. Gumbreck. 1965. Male pseudohermaphroditism with feminizing testes in the male rat. Program of the Endocrine Society. 40. (Abstr.)

5. Bardin, C. W., L. Bullock, G. Schneider, J. E. Allison, and A. J. Stanley. 1970. Pseudohermaphrodite rat: end organ insensitivity to testosterone. Science (Washington). $167: 1136$.

6. Lyon, M. F., and S. G. Hawkes. 1970. X-linked gene for testicular feminization in the mouse. Nature (London). $227: 1217$.

7. Ohno, S., and M. F. Lyon. 1970. X-linked testicular feminization in the mouse as a noninducible regulatory mutation of the Jacob-Monod type. Clin. Genet. 1:121.

8. Wilkins, L. M. 1957. The Diagnosis and Treatment of Endocrine Disorders in Childhood and Adolescence. Charles C. Thomas, Publisher, Springfield, Ill. 2nd edition. 276.

9. Federman, D. D. 1967. Abnormal Sexual Development. W. B. Saunders Company, Philadelphia. 105.

10. Wolff, E. 1953. Le deteriminisme de l'atrophie d'un organe rudimentaire: le conal de Muller des embryons male d'oiseaux. Experientia (Basel). 9: 121.

11. Jost, A. 1953. Problem of fetal endocrinology: the gonadal and hypophyseal hormones. Recent Progr. Hormone Res. 8 : 379.

12. Price, D., and E. Ortiz. 1965. The role of fetal androgen in sex determination in mammals. In Organogenesis. R. L. DeHaan and H. Ursprung, editors. Holt, Rinehart, \& Winston, Inc., New York. 629.

13. Burns, R. K. 1961. Role of hormones in the differentiation of sex. In Sex and Internal Secretions. W. C. Young, editor. The Williams \& Wilkins Co., Baltimore. 3rd edition. $1: 76$.

14. Wilson, J. D., and J. D. Walker. 1969. The conversion of testosterone to $5 \alpha$-androstan-17 $\beta$-ol-3-one (dihydrotestosterone) by skin slices of man. J. Clin. Invest. 48: 371.

15. Heinrichs, W. L., R. Karszinin, R. Wyss, and W. L. Hermann. 1969. Testicular feminization: an apparent enzyme defect. Clin. Res. 17 : 143.

16. Northcutt, R. C., D. P. Island, and G. W. Liddle. 1969. An explanation for the target organ unresponsiveness to testosterone in the testicular feminization syndrome. J. Clin. Endocrinol. Metab. 29: 422.

17. Bullock, L. P., R. J. Sherins, and C. W. Bardin. 1971. Importance of nuclear androgen retention for hormone action. J. Clin. Invest. 50: 15a. (Abstr.)

18. Gehring, U., G. Tomkins, and S. Ohno. 1971. Effect of androgen insensitivity on cytoplasmic receptor for dihydrotestosterone. Nat. New Biol. 232: 106.

19. Bullock, L. P., C. W. Bardin, and S. Ohno. 1971. The androgen insensitive mouse: absence of intranuclear androgen retention in the kidney. Biochem. Biophys. Res. Commun. 44: 1537.

20. Wilson, J. D., and I. Lasnitzki. 1971. Dihydrotestosterone formation in fetal tissues of the rabbit and rat. Endocrinology. 89 : 659.

21. Bruchovsky, N., and J. D. Wilson. 1968. The conversion of testosterone to $5 \alpha$-androstan-17 $\beta$-ol-3-one by rat prostate in vivo and in vitro. J. Biol. Chem. 243: 2012.

22. Frederiksen, D. W., and J. D. Wilson. 1971. Partial characterization of the nuclear reduced nicotinamide 
adenine dinucleotide phosphate: $\Delta^{4}-3$-ketosteroid $5 \alpha$ oxidoreductase of rat prostate. J. Biol. Chem. 246: 2584.

23. Hotta, S., and I. L. Chaikoff. 1955. The role of the liver in the turnover of plasma cholesterol. Arch. Biochem. Biophys. 56: 28.

24. Chauveau, J., Y. Mouli, and C. Rouiller. 1956. Isolation of pure and unaltered liver nuclei. Morphology and biochemical composition. Exp. Cell Res. 11: 317.

25. Burton, K. 1955. Study of the conditions and mechanism of the diphenylamine reaction for the colorimetric estimation of deoxyribonucleic acid. Biochem. J. 62:315.

26. Gruneberg, H. 1971. The glandular aspects of the tabby syndrome in the mouse. J. Embryol. Exp. Morphol. 25: 1.

27. Bardin, C. W., J. E. Allison, A. J. Stanley, and L. G. Gumbreck. 1969. Secretion of testosterone by the pseudohermaphroditic rat. Endocrinology. 84: 435.

28. Southren, A. L. 1965. The syndrome of testicular feminization. Advan. Metab. Disord. 2: 227.

29. Kase, N., and J. M. Morris. 1965. Steroid synthesis in the cryptorchid testes of three cases of the testicular feminization syndrome. Amer. J. Obstet. Gynecol. 91: 102.

30. Beach, F. A., and A. M. Holz. 1946. Mating behavior in male rats castrated at various ages and injected with androgen. J. Exp. Zool. 101: 91.

31. Grady, K. L., C. H. Phoenix, and W. C. Young. 1965. Role of the developing rat testis in differentiation of the neural tissues mediating mating behavior. J. Comp. Physiol. Psychol. 59: 176.
32. Albert, A. 1961. The mammalian testis. In Sex and Internal Secretions. W. C. Young, editor. The Williams \& Wilkins Co., Baltimore. 3rd edition. 1: 305.

33. Wilson, J. D., and R. E. Gloyna. 1970. The intranuclear metabolism of testosterone in the accessory organs of reproduction. Recent Progr. Hormone Res. 26: 309.

34. Gloyna, R. E., and J. D. Wilson. 1969. A comparative study of the conversion of testosterone to $17 \beta$-hydroxy$5 \alpha$-androstan-3-one (dihydrotestosterone) by prostate and epididymis. J. Clin. Endocrinol. Metab. 29: 970.

35. Raynaud, J. 1960. Controll hormonal de la glande sousmaxillarie de la souris. Bull. Biol. Fr. Belg. 94: 399.

36. Junqueira, L. C. U., A. Fajer, M. Rabinovitch, and L. Frankenthal. 1949. Biochemical and histochemical observations on the sexual dimorphism of mice submaxillary glands. J. Cell Comp. Physiol. 34: 129.

37. Levi-Montalcini, R., and P. U. Angeletti. 1964. Hormonal control of the NGF content in the submaxillary glands of mice. Salivary Glands Their Secretions Proc. Int. Conf. 3: 129.

38. Hall, P. F. 1970. Endocrinology of the testes. In The Testis. A. D. Johnson, W. R. Gomes, and N. L. Vandemark, editors. Academic Press, Inc., New York. 2: 1.

39. Hauser, G. A. 1963. Testicular feminization. In Intersexuality. C. Overzier, editor. Academic Press, Inc., New York. 255.

40. Hall, P. F., D. C. Irby, and D. M. de Kretser. 1969. Conversion of cholesterol to androgens by rat testes: comparison of interstitial cells and seminiferous tubules. Endocrinology. 84: 488.

41. Wilson, J. D. 1971. Testosterone metabolism in skin. Symp. Deut. Ges. Endokrinol. $17: 11$. 